\title{
Moral Realism in Spinoza's Ethics
}

\author{
Colin Marshall \\ University of Washington
}

One of Spinoza's apparent goals in the Ethics is to revise commonsense morality. This raises a question: do Spinoza's revisions show that he thought morality was somehow unreal? In this chapter I argue that, despite his revisionism, Spinoza's metaethical views in the Ethics are a form of moral realism, even though they contain anti-realist elements. ${ }^{1}$

In so arguing, I hope to bring Spinoza's commentators and contemporary metaethicists into better conversation with each other. The terms "moral realism" and "moral anti-realism" entered the standard philosophical vocabulary only in the late $20^{\text {th }}$ century, and many interpretive issues about Spinoza can be adequately discussed without using any contemporary metaethical categories. I hope to show, however, that attempting to classify Spinoza metaethically both raises important interpretive questions and shows that Spinoza's views bear on various general metaethical issues. Many commentators, I believe, could benefit from closer attention to the details of contemporary metaethics, but contemporary metaethicists could also benefit from closer attention to the complexities of Spinoza's metaethics.

Metaethicists use the moral realism/anti-realist distinction to characterize a debate that supposedly goes back at least to Plato. I begin, therefore, by discussing the contemporary understanding of that distinction $(\S 1)$, which has received limited attention from Spinoza scholars. I then survey common reasons for anti-realist readings of Spinoza (§2), before describing the moral realist elements of his views $(\S 3)$. I then consider the metaethical significance of his revisionism ( $\$ 4)$, and conclude by saying why, all things considered, Spinoza is best classified as a moral realist (§5).

A preliminary note: Spinoza himself does not explicitly distinguish between moral value

\footnotetext{
${ }^{1}$ Anti-realist readings are more common than realist readings. For an overview of recent interpretations, see the introduction in Kisner and Youpa, Essays on Spinoza's Ethical Theory, pp. 3-12.
} 
and other types of practical value (e.g. prudential value). This makes it harder for any isolated passage to decide in favor of a realist or anti-realist reading, since any given passage can be read in a non-moral way. Many of Spinoza's readers have assumed, however, that at least some of his general claims about value apply to what we today count as moral value. I rely on that assumption below. $^{2}$

\section{Moral Realism and Anti-Realism}

In recent years, a number of Spinoza's commentators have classified him as either a moral realist or anti-realist. Most of those commentators assume that the distinction is a straightforward one. In fact, the distinction between moral realism and anti-realism has been approached in at least three ways. ${ }^{3}$ These approaches focus either on (i) paradigmatic views, (ii) the truth of moral claims, or (iii) certain defining features of realism: mind independence, nonrelativity, and (occasionally) an opposition to egoism. These approaches are interrelated, but not equivalent. In this section, I briefly discuss each approach and note some complications involved in applying the realism/anti-realism distinction to Spinoza.

In perhaps the most influential discussion of the moral realism/anti-realism distinction, Geoffrey Sayre-McCord writes,

[t]he realism/anti-realism debate in ethics has been around ever since people began thinking critically about their moral convictions. The problem has always been to make sense of these convictions in a way that does justice to morality's apparent importance without engaging in outrageous metaphysical flights of fancy. Some have thought it can't be done; they've held that the apparent importance of morality is mere appearance. Others have thought it can be done; they've held that whatever metaphysics is necessary is neither outrageous nor fanciful. ${ }^{4}$

In talking of "outrageous metaphysics flights of fancy," Sayre-McCord probably has in mind Plato's view in The Republic, which appeals to the Form of the Good. The Form of the Good (on the traditional reading of Plato) is something that exists outside the natural world and gives rise to knowledge, including moral knowledge, and to moral virtue. Plato illustrates the relation between

\footnotetext{
${ }^{2}$ For one helpful discussion, see Kisner, Spinoza on Human Freedom, pp. 128-130.

${ }^{3}$ Some of the complexities in the moral realism/anti-realism distinction come from broader complexities about the general realism/anti-realism distinction. For one important discussion, see Wright, Truth and Objectivity.

${ }^{4}$ Sayre-McCord, Essays on Moral Realism, p. 2.
} 
the Form of the Good and the natural world with the analogy of the sun, which exists outside the earth but gives rise to light and life. ${ }^{5}$ Plato's view is a paradigm of moral realism. By contrast, in talking of those who hold that the apparent importance of morality is "mere appearance," one view Sayre-McCord probably has in mind is J. L. Mackie's. Mackie claims that all moral judgments presuppose a radical but false metaphysics like Plato's. He therefore endorses an error theory, according to which all (positive) moral statements are false. ${ }^{6}$ Mackie's view is a paradigm of moral anti-realism. Other paradigms of anti-realism are the views of Hobbes, Hume, and Nietzsche. At the same time, some major figures in metaethics have a more controversial status, and their views are not clear paradigms of either moral realism or anti-realism. The most important such figure is Kant. ${ }^{7}$ One approach to determining whether Spinoza is a moral realist, therefore, would involve comparing him to various paradigms. Call this the Paradigm Approach.

Sayre-McCord does not ultimately use paradigms to define the difference between moral realism and anti-realism, however. Instead, he proposes that a view counts as a form of moral realism if and only if it says that (positive) moral claims (a) "when literally construed, are literally true or false" and (b) that "some are literally true." ${ }^{\prime 8}$ Sayre-McCord seems to think that this approach correctly classifies all paradigmatic moral realists and anti-realists. If so, it would subsume the Paradigm Approach. Whether or not it does, this proposal (or variants of it) is probably the most widely-accepted way of drawing the moral realism/anti-realism distinction. On this second approach to the moral realism/anti-realism distinction, determining whether Spinoza is a moral realist would involve determining whether he accepts both (a) and (b). Call this the Literal Truth Approach.

The Literal Truth Approach is not uncontroversial, though. One common worry is that moral anti-realists might be able to satisfy (a) and (b) using a 'deflationary' notion of truth. ${ }^{9}$ Another worry, more relevant to Spinoza, stems from a third approach to the moral-realism/antirealism distinction. On this approach, moral realism crucially involves taking morality (i.e. moral facts) to have certain defining features that make it robustly 'real,' namely, that morality be absolute (i.e., non-relative), mind-independent, and perhaps also opposed to normative egoism.

\footnotetext{
${ }^{5}$ See Republic, Book 6.

${ }^{6}$ Mackie, Ethics. The restriction to positive claims is needed, since an error theorist could agree that (e.g.) "love is not morally impermissible" is true.

${ }^{7}$ For a helpful discussion, see Kain, "Realism and Anti-Realism."

${ }^{8}$ Sayre-McCord, Essays on Moral Realism, p. 5.

${ }^{9}$ See Dreier, "Creeping Minimalism."
} 
Sayre-McCord's conditions, however, do not obviously require any of these defining features. ${ }^{10}$ The most straightforward way to bridge this difference would be to focus on the "literal construal" part of Sayre-McCord's proposal, and hold that a literal construal of moral claims requires taking them to refer to mind-independent, non-relative, and/or anti-egoistic facts. It is a difficult question whether that bridging strategy would be correct. ${ }^{11}$ Either way, if we took this third approach, determining whether Spinoza is a moral realist involve determining whether he takes morality to be absolute, mind-independent, and/or anti-egoistic in the relevant ways. We can call this the Defining Features Approach, though different versions of this approach would focus on different defining features.

These three approaches might ultimately come to the same thing. Prima facie, though, they are quite different. It might be that no way of filling out the last two approaches draws the intuitive distinction between paradigmatic views. Moreover, the literal truth of moral claims might require none of the relevant defining features. We should be open to the possibility, therefore, that these approaches will yield different answers to the question of whether Spinoza is a moral realist. At a minimum, they suggest different argumentative strategies.

Despite their potential differences, though, none of these approaches suggests that revisionism about moral concepts must imply anti-realism. Plato, a paradigmatic realist, was probably a revisionist of some sort. Non-philosophers, after all, would not think "good" could refer to an entity like the Form of the Good. ${ }^{12}$ In fact, for Plato, it could turn out that the only literally true moral claims were ones made using revised concepts (though, to be sure, there is some tension between literalness and revision). ${ }^{13}$ For similar reasons, it might be that the relevant absolute, mind-independent (and perhaps anti-egoist) facts for Plato are ones that are describable only by the revised concepts. Perhaps some revisions are incompatible with moral realism, then, but if so, the incompatibility is not straightforward.

\footnotetext{
${ }^{10}$ For discussions of relativity and mind-dependence, see Findlay, "Four Faces" and Harman, "Moral Relativism." For an argument that morality is opposed to egoism see Schopenhauer, On the Basis of Morals. As Nadler, "The Lives of Others" emphasizes, opposing egoism to morality is a largely postKantian trend. Plato's metaethics, for example, is not opposed to every kind of egoism. Nowhere I know of in the recent non-historical metaethics is egoism opposed to moral realism. Note that normative egoism does not straightforwardly imply mind-dependence or relativity.

${ }^{11}$ My own view is that such a strategy would be problematic. A deeper question is whether moral realism must concern moral claims at all. I discuss this issue in "Schopenhauer and Non-Cognitivist Moral Realism."

${ }^{12}$ See Annas, "Plato and Common Morality." See also Theaetetus, 174c-175b on how philosophers' views of value differ from non-philosophers' views.

${ }^{13}$ As an example of literal truth with a revised concept, consider the literally true claim that marriage need not involve any property-exchange, even though the concept of marriage once did require propertyexchange.
} 
I want to note three further things about the Literal Truth Approach in particular, given its importance in contemporary metaethics. First, Sayre-McCord's proposal is not a stipulative definition. Instead, it aims to characterize a philosophical division that has been around "ever since people started thinking critically about their moral convictions." Second, this approach does not specify whose moral claims are in question. It leaves open that the only true moral claims are those made by philosophers who revise commonsense moral concepts. This flexibility is needed for applying the distinction to views like Plato's. Finally, on the Literal Truth Approach, it is sufficient for moral realism if only a small fraction of moral claims are literally true. Moral realism could hold, on this approach, even if the vast majority of philosophers' and nonphilosophers' moral discourse were false, or not even truth-apt. This last feature may also hold for the other two approaches as well. ${ }^{14}$

In sum, then, there are at least three approaches to capturing the intuitive distinction between moral realism and anti-realism. To begin evaluating how Spinoza should be classified on these approaches, we can consider the grounds previous interpreters have offered for taking Spinoza to be a moral anti-realist.

\section{Anti-Realist Elements}

Most discussions of Spinoza's metaethics ignore the above subtleties concerning the moral realism/anti-realism distinction. Partly because of that, interpreters who read Spinoza as an anti-realist often simply assume one approach to the distinction, ignoring the others.

My aim in this section is to summarize the chief textual motivations in the Ethics for antirealist readings: (1) Spinoza's claims about the historical and psychological origins of moral notions and moral views, (2) Spinoza's claims about the relativity of value and its connections to egoism, (3) Spinoza's appeal to a model of human nature, and (4) Spinoza's radically permissive views about natural rights.

\subsection{The origins of morality}

Spinoza concludes Book 1 with remarks about how humans came to have moral notions and moral views. After describing how humans came to falsely believe that they had absolutely

\footnotetext{
${ }^{14}$ There is an additional approach that occasionally surfaces in the metaethics literature (e.g. Street, "Reply to Copp," 223): taking moral realism to posit an epistemic asymmetry between morally good and morally bad people. For reasons given in $\S 3.3$ below, this approach strongly favors counting Spinoza as a moral realist.
} 
free will and that natural things had human-directed purposes, he states,

[a]fter men persuaded themselves that everything which happens, happens on their account, they had to judge that what is most important in each thing is what is most useful to them, and to rate as most excellent all those things by which they were most pleased. Hence they had to form these notions, by which they explained natural things: good, evil, order, confusion, warm, cold, beauty, ugliness. And because they think themselves free, those notions have arisen: praise and blame, sin and merit. (E1app, G II

Spinoza seems to be saying that humans' moral notions arose from metaphysical mistakes. He does not say that moral claims are therefore false, but it would be a small step from what he says here to a Mackiean error theory. Sayre-McCord himself notes that "on some plausible interpretations," Spinoza is an early defender of error theory. ${ }^{15}$

Spinoza's claims about these notions after Book 1 generally sound less skeptical. Nonetheless, he gives an anti-realist-sounding account of moral judgments. In E3p9s, he writes that "we neither strive for, not will, neither want, nor desire anything because we judge it to be good; on the contrary, we judge something to be good because we strive for it, will it, want it, and desire it" (cf. E3p39s). To some commentators, this sounds like a mind-dependence-focused rejection of realism (denying a defining feature) that anticipates Hume's views (a paradigm antirealist). ${ }^{16}$

In a related vein, Spinoza holds that an epistemically superior being would not have notions like goodness and badness. In E4p68, he writes that "[i]f men were born free, they would form no concept of good and evil so long as they remained free." In 4p68d, he reminds us that free men live by reason and adequate ideas alone. That means the free man is epistemically

\footnotetext{
${ }^{15}$ Sayre-McCord, Essays on Moral Realism, p. 10. See also Koistinen and Biro, Spinoza: Metaphysical Themes, p. 8 and Jarrett, "Spinozistic Constructivism," p. 80. Spinoza tells similarly skeptical stories about ordinary notions of universals (see E2p40s1) and about common views about perfection (see E4pref). If moral notions concern universals and perfections, these passages could be read as continuing the errortheoretic origin story from Elapp. Alternatively, if Spinoza held that language is unable to express philosophical truth (see Savan, "Spinoza and Language"), he might be an error theorist about all philosophically-significant discourse, moral and non-moral.

${ }^{16}$ Garrett, "Spinoza's Ethical Theory," p. 287 thinks this remark suggests emotivism. Emotivism is a form of moral anti-realism that would involve rejecting both of Sayre-McCord's conditions. Frankena, "Spinoza on the knowledge of good and evil," p. 17 makes a similar claim about E4p8 ("The knowledge of good and evil is nothing but an affect of joy or sadness, insofar as we are conscious of it"). E4p8 is better support for an emotivist reading than E3p9s, for the latter can be read as a psychological claim without metaethical import.
} 
superior to normal humans. The free man's lack of moral notions, one might conclude, indicates that those notions have no real bearing on reality. This suggests anti-realism on the Paradigm Approach, since it resembles the views of paradigm anti-realists like Nietzsche. ${ }^{17}$

\subsection{The relativity of value and tie to egoism}

Spinoza does not dismiss all moral terms after E1app, but instead makes use of them himself in Books 3-5. This shows that Spinoza was not a straightforward error theorist. Nonetheless, much of what he says in Books 3 and 4 suggests a relativist, egoist approach to value. This has struck many of Spinoza's readers as showing that he accepted a form of broadly Hobbesian moral anti-realism.

Though the relativism and egoism in Spinoza's theory of value are linked, they have different anti-realist overtones. Consider the relativism first. In E3p39s, Spinoza uses "good" and "bad" as simple descriptions of joy and sadness. In the E4pref, Spinoza notes that these terms "indicate nothing positive in things, considered in themselves, nor are they anything other than modes of thinking, or notions we form because we compare things to one another." He states, though, that he will retain these terms, and offers new definitions of them: "By good I shall understand what we certainly know to be useful to us" (E4d1), "By evil, however, I shall understand what we certainly know prevents us from being masters of some good" (E4d2). ${ }^{18}$

Two aspects of these claims suggest anti-realism, especially in accordance with the Defining Features Approach. First, there is the thought that anything relational or relative is not fully real. This thought appears in Spinoza's early writings. ${ }^{19}$ Second, even if relativism does not suggest unreality in all domains, one might think that relativism about value is opposed to specifically moral realism. For paradigmatic forms of moral realism like Plato's, for example, there is exactly one correct moral view. By contrast, Spinoza's relativist statements seem to allow for a wide range of equally correct moral views, provided that different things are certainly

\footnotetext{
${ }^{17}$ On this comparison, see Curley, Behind the Geometrical Method, p. 128; Melamed, "Spinoza's Metaphysics of Substance," pp. 51-53. This point does not directly connect to the Literal Truth or Defining Features Approaches, since some non-relative, mind-independent facts (e.g. non-fundamental facts) might be ignored by epistemically superior beings.

${ }^{18}$ For a relativist reading of these claims, see Miller, "Spinoza's Axiology" (but cf. Youpa, "Spinoza's Theories of Value," p. 222). Surprisingly, Spinoza continues to use the meaning of the terms described earlier in the preface later in Book 4 (see E4p65d). A number of commentators have thought Spinoza shifts between a commonsense view of value and his own theory (in particular, Bennett, A Study of Spinoza's Ethics, Chapter 12, though again cf. Youpa, "Spinoza's Theories of Value").

${ }^{19}$ See KV I 10, G I/49.
} 
known to be useful to different creatures.

The "useful to us" in E4d1 points at the connection between Spinoza's egoism (traceable back to his conatus doctrine at E3p6) and his theory of value. Spinoza is explicit about this egoism, saying at E4p22c that self-preservation is the "first and only foundation of virtue." In a letter to Willem van Blyenbergh, Spinoza acknowledges the radical implications of this view. $\mathrm{He}$ writes that someone "who saw clearly that in fact he would enjoy a better and more perfect life or essence by being a knave than by following virtue would also be a fool if he were not a knave. For acts of knavery would be virtue in relation to such a perverted human nature" (Ep23, G IV 152).

Even though Spinoza's egoism is unlike Hobbes' in important respects, ${ }^{20}$ some philosophers have thought that normative egoism was incompatible moral with realism, regardless of whether it is coupled with relativism. Therefore, there is a case for classifying Spinoza as a moral anti-realist on either the Paradigm Approach or the Defining Features Approach. This case could be extended to the Literal Truth Approach, if we assumed that a literal construal of moral claims must be anti-egoist. The same might be said of the next two motivations for the anti-realist reading.

\subsection{The model we set before ourselves}

When Spinoza states that he will retain the terms "good" and "bad" in 4pref., he talks of a model of human nature: "in what follows I shall understand by good what we know certainly is a means by which we may approach nearer and nearer to the model of human nature that we set before ourselves." This model is not explicitly mentioned in E4d1 or E4d2, though most commentators take Spinoza's later discussion of the free man starting at E4p66s to be a description of that model. ${ }^{21}$ It is also plausible that Spinoza's discussion of value earlier in Book 4 is made with the model in mind. While this issue is probably connected to Spinoza's relativism and egoism, Spinoza's reference to the model of human nature has played a distinctive role in motivating anti-realist readings. ${ }^{22}$

The idea that morality is based on a model we set before ourselves might, via the

\footnotetext{
${ }^{20}$ See E4p36s. For relevant discussions, see Steinberg, "Spinoza's Ethical Doctrine," Garrett, "Spinoza's Ethical Theory," pp. 302-05, Youpa, “Spinoza's Theory of the Good," LeBuffe, From Bondage to Freedom, Ch.5, Nadler, "The Lives of Others," and Zuk, "Rethinking Spinoza's Metaethics."

${ }^{21}$ But see Kisner, Spinoza on Human Freedom, Ch. 8.

${ }^{22}$ See Jarrett, "Spinozistic Constructivism" and Rosenthal, "Politics and Ethics in Spinoza."
} 
Defining Features Approach, suggest anti-realism in two ways. First, it might suggest that morality is arbitrary. That is, it might allow that moral facts could have been different if we had chosen a different model, or that moral facts are different for different people because of their choice of models. ${ }^{23}$ These would seem to be forms of relativism, albeit relativism approached from a different angle than in E4d1 and E4d2.

The second anti-realist implication is subtler. Even if there were only one possible model of human nature, the appeal to a model would still suggest that moral facts are derived from facts about human choice and action. If morality is a human 'construction,' then it is mind-dependent in some way, and mind-dependence is a traditional mark of anti-realism. This might hold even if there were no arbitrariness, that is, even if morality could not have been constructed differently. ${ }^{24}$

In addition, if Spinoza's model is the free man, then that model might not be fully attainable for actual humans, since actual humans cannot be completely free (see E4p4). ${ }^{25}$ This could add support to the anti-realist reading. For if morality is based on a model that cannot be real, then it might seem that morality itself cannot be real. The simplest way to formulate an argument along these lines would be to take the Defining Features Approach focus on reality itself (applied to moral ideals or models) as a crucial defining feature of moral realism.

\subsection{Natural right}

Spinoza makes radically permissive claims about natural rights. The connection between natural rights and morality is complex, but a radically permissive view about the former would be more easily paired with moral anti-realism than with moral realism, especially if we reflect on certain paradigmatic anti-realists.

Spinoza's best-known discussion of natural rights appears in Chapter 16 of the TTP, where he writes that since "Nature's right is co-extensive with her power... each individual thing has the sovereign right to do all that it can do," and that "the natural right of every man is determined not by sound reason, but by his desire and his power" (G III 189). Similar claims

\footnotetext{
${ }^{23}$ Curley, "Spinoza's Moral Philosophy" and Youpa, "Spinoza's Theories of Value," p. 217 read it as having this implication.

${ }^{24}$ Kisner, "Perfection and Desire" seems to take this kind of line (see also Kisner, Spinoza on Human Freedom, pp. 96-99 on subjectivism, Spinoza's "irrealist conception of the good," and the model). Aside from the Defining Features Approach, one could also reach this anti-realist conclusion from the view that only the fundamental is real (e.g. Fine, "The Question of Realism"). Note that the Defining Features Approach can come apart from the Literal Truth Approach here, if this human construction is compatible with the literal truth of some moral claims.

${ }^{25}$ For an influential discussion, see Garrett, "A Free Man Always Acts Honestly."
} 
appear in the Ethics:

everyone, by the highest right of Nature, judges what is good and what is evil... avenges himself... and strives to preserve what he loves and destroy what he hates... in the state of nature... [one] is not bound by any law to submit to anyone except himself... [and] in the state of nature nothing is done which can be called just or unjust (E4p37s2)

It is permissible for us to avert, in the way that seems safest, whatever there is in nature that we judge to be evil... we may take for our own use, and use in any way, whatever there is that we judge to be good... And absolutely, it is permissible for everyone to do, by the highest right of Nature, what he judges will contribute to his advantage.

$(\mathrm{E} 4 \mathrm{app} 8)^{26}$

Strictly speaking, these claims are compatible with realism about, say, goodness, provided that facts about goodness do not significantly limit facts about permissibility and natural rights. Yet Spinoza seems to think that goodness and badness are closely tied to natural rights. This is suggested by how Spinoza seems to ground both in the conatus doctrine. Since some paradigmatic anti-realists like Hobbes held similarly permissive views about natural rights, it is therefore easy to see why the passages concerning natural rights have struck some of Spinoza's readers as evidence for him being a moral anti-realist. ${ }^{27}$

Assuming the above readings are correct, there are therefore reasons to call Spinoza an anti-realist. Some of Spinoza's claims resemble those of anti-realists like Nietzsche, Hume, and Hobbes (Paradigm Approach); he seems to regard at least some moral claims as false, and others as at least not literally true (Literal Truth Approach); and he seems to regard at least some significant parts of morality as relative, mind-dependent, and egoistic (Defining Features Approach). The next question is whether there are realist elements in his views that could outweigh these anti-realist elements.

\section{Realist Elements}

\footnotetext{
${ }^{26}$ I have elided two clauses that weaken this passage's anti-realist overtones.

${ }^{27}$ See Rosenthal, "Politics and Ethics in Spinoza," whose argument also appeals to 4pref.'s model of human nature. Rosenthal thinks Spinoza posits significant constraints and norms via anti-realist means.
} 
While Spinoza expresses some skepticism about commonsense morality, he also suggests a commitment to vindicating morality in some sense. In E4p18s, Spinoza claims this his egoism provides the ground of virtue and morality [pietas]. Writing to Willem van Blijenbergh, he states that "the Philosophers ... follow virtue not as a law, but from love, because it is the best thing" (Ep19, G IV 93). There is also the fact that the title he chose for his central philosophical work was "Ethica."

At best, though, those points provide superficial evidence for the realist reading, not least because of difficult questions about the meanings of "pietas" and "ethica." In this section, I describe three deeper aspects in Spinoza's philosophy that support counting him as a moral realist, namely: (1) Spinoza's Dictates of Reason appear to be prescriptive claims with a deeper metaphysical grounding than Kant's moral principles, (2) Spinoza identifies virtue with something robustly real, and (3) Spinoza posits something that closely resembles the paradigmatic (mind-independent, absolute) metaphysical posit of moral realism: Plato's Form of the Good.

\subsection{Kant and the Dictates of Reason}

Like Spinoza, Kant sees morality as essentially connected to reason. As I noted above, it is controversial whether Kant should be counted as a moral realist or an anti-realist. What is relatively uncontroversial, though, is that Kant is a better contender for being a moral realist than either Hobbes, Hume, or Nietzsche. There is a case to be made, though, that Spinoza's view of reason is even closer to moral realism than Kant's.

There are many readings of Kant's metaethics, but one common reading takes him to make the following claims. The core moral principle is (or is expressed by) an imperative that arises from our faculty of reason. This faculty and its imperative cannot be changed by us. We have no genuine knowledge of the ultimate source of this faculty, and so cannot rule out that it has no deeper basis than our own nature. ${ }^{28}$ If reason had no deeper basis than our own nature, though, then it would follow that morality was mind-dependent in a certain sense. Such mind-

\footnotetext{
${ }^{28}$ In "Kant's Derivation of the Moral 'Ought', ' I offer an interpretation of Kant that makes the contrast with Spinoza clear. That interpretation takes Kant to see reason as a causal power that is also normative. For a related reading of Spinoza on reason and the Dictates, see Rutherford, "Spinoza and the Dictates of Reason." Rutherford takes the Dictates to be non-prescriptive, however, because of the considerations described in $\$ 2.4$ above and because of he thinks that reason cannot be both prescriptive and a causal power. Lebuffe, "Necessity and the Commands of Reason" argues that the dictates of reason are tenets of common sense, which the prescriptions of Book 5 are meant to go beyond.
} 
dependence would at least partly align Kant with some paradigmatic anti-realists. ${ }^{29}$

In E4p37s1, Spinoza says: "[t]he desire to do good generated in us by our living according to the guidance of reason, I call Morality [pietatem]." In E4p18s, Spinoza describes the effect of reason on our actions in terms of a collection of 'dictates.' In these respects, he sounds quite close to Kant (see also the Kantian-sounding E4p72d). ${ }^{30}$ Unlike Kant, however, Spinoza holds that reason does have a deeper basis than human nature. Spinoza claims that reason is what provides us with knowledge "from the fact that we have common notions and adequate ideas of the properties of things" (E2p40s2). Shortly before, in E2p40s1, Spinoza states that common notions are "the foundations of our reasoning." E2p37-E2p40 show that common notions are adequate ideas of common properties of things, which are properties of all wholes and their parts. These common properties are, therefore, not human-dependent (nowhere in his discussion of reason does Spinoza appeal to anything like an arbitrarily-chosen model). By the parallelism of E2p7, then, the common notions are likewise not human-dependent (though see Grey, "Animal Ethics," on E2p39). ${ }^{31}$ For Spinoza, therefore, the foundations of reason are not dependent on finite minds in the way that Kant seems to allow. On one important dimension, then, Spinoza's views sound more like moral realism than do Kant's. In accordance with at least the Paradigm Approach, there therefore is a case for taking Spinoza to be a moral realist. ${ }^{32}$

I should note one complication. The Dictates Spinoza lists at the middle and end of E4p18s sound like familiar parts of morality: "we ought to want virtue for its own sake... men who are governed by reason... want nothing for themselves that they do not desire for other men. Hence, they are just, honest, and honorable" (E4p18s). This shows that Spinoza's pietas at least partly overlaps with our sense of morality, and shows that Spinoza's revisionism is not extreme. The Dictates begin, though, with egoistic-sounding statements: "Since reason demands nothing contrary to nature, it demands that everyone love himself, seek his own advantage, what is really

\footnotetext{
${ }^{29}$ For a relevant discussion, see Rauscher, "Kant's Moral Anti-Realism."

${ }^{30}$ Another important area of similarity is the connections that Kant and Spinoza see between morality and freedom. See Kisner, Spinoza on Human Freedom, which also discusses how, for both thinkers, this freedom hinges on impartial and universalizable rules.

${ }^{31}$ They are, of course, dependent on God. But God-dependence is unlike human-dependence. In the TTP, Spinoza writes that, "divine commandments seem to us like decrees or enactments only so long as we are ignorant of their cause. Once we know this, they immediately cease to be edicts and we accept them as eternal truths, not as decrees, that is, obedience immediately turns into love which arises from true knowledge as inevitably as light emanates from the sun" (Annotation 34, G III 264, see also 1app). The mention of the sun here will be relevant below.

${ }^{32}$ One could object that Spinoza's Dictates are not normative in the way that Kant's are. Since Spinoza uses the language of "ought"s and "demands," though, it is hard to see what would motivate this objection, though, besides a background assumption of anti-realism.
} 
useful to him... the foundation of virtue is this very striving to preserve one's own being" (E4p18s). While Kant has also been accused of a fundamentally egoistic morality, ${ }^{33}$ he never makes comparably egoistic claims. If, as some proponents of the Defining Features Approach might claim, egoism is inconsistent with moral realism, then, Spinoza may not be straightforwardly more realist than Kant. On the Literal Truth Approach, though, egoism threatens moral realism only if it challenges the condition that moral claims be literally construed. A similar complication applies to the next realist element of Spinoza's philosophy.

\subsection{The Reality of Virtue}

In E4d8, Spinoza identifies a central moral concept, that of virtue, with something clearly real: "By virtue and power I understand the same thing, i.e. (by E3p7), virtue, insofar as it is related to man, is the very essence, or nature of man, insofar as he has the power of bringing about certain things, which can be understood through the laws of his nature alone." In E4pref (following E2d6) Spinoza identifies reality with "the essence of each thing insofar as it exists and produces an effect." Taking these claims at face value, Spinoza equates the virtue of a being with that being's reality, since he equates each with essence-insofar-as-it-produces-effects. This appears to make part of morality robustly real, which suggests moral realism on the Defining Features Approach. ${ }^{34}$ Further, no paradigmatic moral anti-realist identifies virtue with a thing's reality, so the Paradigms Approach also suggests moral realism here. Finally, these claims show that Spinoza's views satisfy Sayre-McCord's two conditions. Spinoza clearly takes some statements about power and reality to be true, and if virtue is definitionally identified with power and reality, then a case can be made that some statements about virtue are not just true, but true on a literal construal.

The last appeal to the Literal Truth Approach hinges on the assumption that if (I) $\mathrm{x}$ is definitionally identified with y and (II) some statements about y are true on a literal construal, then at least one statement about $\mathrm{x}$ is true on a literal construal. That assumption might be challenged, especially if the definitional identification involves a revision of the normal sense of one of the concepts being defined. This may be the case with the concept of virtue in E4d8, especially if it is part of the normal sense of "virtue" that it is opposed to egoism. For the power involved in virtue is the exercise of the conatus, which is the striving of a thing to persevere in its

\footnotetext{
${ }^{33}$ Schopenhauer, On the Basis of Morals, §7.

${ }^{34}$ On power and existence, see also E1p11d3. For a broadly similar argument, see Kisner and Youpa, introduction to Essays on Spinoza's Ethical Theory, p. 7.
} 
own being (see E3p6-7), and this sounds obviously egoistic. In addition, since the conatus is essential to our minds (E3p7), and the conatus for different minds can differ (most clearly, between species; see E3p57s), there is a certain sense in which E4d8 makes virtue into something mind-dependent and relative. I return to these complexities in $\S 4$ and $\S 5$.

\subsection{Spinoza's God and Plato's Form of the Good}

Perhaps the most important element of Spinoza's philosophy that suggests moral realism concerns God. I propose that the existence of Spinoza's God is sufficient for the literal truth of what is arguably Plato's central moral claim, namely, that there is a Form of the Good. ${ }^{35}$ If Spinoza's philosophy posits something similar to Plato's Form of the Good (regardless of what terms Spinoza uses for that entity), then that would bring his philosophy very close to the main paradigm of moral realism. Here is an analogy. Say that some philosopher denies that God exists, but goes on to affirm the existence of a single supernatural being that created the universe, intervenes in the natural world in response to human petitions, and distributes justice in the afterlife. We might conclude that, despite her claims to atheism, that philosopher was in fact a realist about God. Analogously, I suggest, Spinoza has a Platonic moral metaphysics.

As with Kant, there are many different interpretations of Plato's metaethics. Many readers, though, have seen moral realism in Books 6 and 7 of The Republic. In Book 6, Socrates claims that "not only do the objects of knowledge owe their being known to the good, but their existence and being are also due to it; although the good is not being, but something yet beyond being, superior to it in rank and power" (509b). In Book 7, he claims that

in the knowable realm, the last thing to be seen is the [F]orm of the [G]ood, and it is seen only with toil and trouble. Once one has seen it, however, one must infer that it is the cause of all that is correct and beautiful in anything, that in the visible realm it produces both light and its source, and that in the intelligible realm it controls and provides truth and understanding; and that anyone who is to act sensibly in private or public must see it $(517 b)$

\footnotetext{
${ }^{35}$ As far as I know, none of Spinoza's readers have considered the specifically metaethical significance of the similarities between Spinoza's God to Plato's Form of the Good. For recent discussions of Platonic aspects of Spinoza's philosophy, see the essays in Ayers, Rationalism, Platonism and God. For background on Spinoza's access to Neoplatonic authors, see Kristeller, "Stoic and NeoPlatonic Sources." For a comparison of Spinoza with Plato (beyond just neo-Platonism), see Hart, Spinoza's Ethics. Spinoza is critical of Plato on various points (see, e.g., Ep56), but not in ways that threaten the point I make here.
} 
On the traditional reading of such passages, Plato is positing an entity that is:

(i) the source of all other things,

(ii) on analogy with the sun, the source of truth and the highest knowledge,

(iii) known only with difficulty,

(iv) a guide to virtuous action,

(v) answerable to no higher standard, and

(vi) radically unlike fallible finite agents in a way that is inconsistent with mainstream monotheism.

One implication of this view is that people who act viciously must be ignorant of the ultimate nature of reality.

Spinoza never identifies God and the good, though he says knowledge of God is our highest good (E4p28). He was probably not directly influenced by Plato's writings. Nonetheless, his God has these six features. Spinoza claims that:

(i) God is "the immanent... cause of all things" (E1p18),

(ii) "[a]ll ideas, insofar as they are related to God, are true" (E2p32) and the highest kind of knowledge "proceeds from an adequate idea of the formal essence of certain attributes of God" (E2p40s2), on analogy with the sun (see TTP Annotation 34, G III 264, DPP 1p15s),

(iii) adequate knowledge of God is as difficult as it is rare (E5p42s),

(iv) "[t]he good which everyone who seeks virtue wants for himself, he also desires for other men; and this Desire is greater as his knowledge of God is great" (E4p37, see also E5p20), ${ }^{36}$

(v) "[n]othing more absurd can be maintained about God" than that there is "something outside God... to which God attends, as a model" (E1p33s), and

(vi) "the intellect and will which would constitute God's essence would have to differ entirely from our intellect and will, and could not agree with them in anything except the name" (E1p17s), the heretical implications of which are obvious. ${ }^{37}$

\footnotetext{
${ }^{36}$ Youpa, "Spinoza's Model" argues that one of Spinoza's models of human nature just is God. Hegel claims that the "great principle" of Spinoza's system of morals was that "the finite spirit is moral in so far as it has the true Idea, i.e. in so far as it directs its knowledge and will on God, for truth is merely knowledge of God" (Hegel, Lectures, p. 275), so that there is "no ground for the objection that Spinoza's philosophy gives the death blow to morality" (Hegel, Lectures, p. 279).

${ }^{37}$ One might object that Plato's Form is intrinsically normative, while Spinoza's God is not. This is a difficult issue, but since Spinoza does make God the source of reason (including the Dictates of Reason), there is a case to be made that God is intrinsically normative (cf. Mackie, Ethics, p. 40). See Spinoza's talk
} 
These fifth and sixth features make Spinoza's conception of God closer to Plato's Form of the Good than most other early modern conceptions of God.

This comparison straightforwardly supports counting Spinoza as a realist on the Paradigm Approach, but yields arguments for the other two approaches as well. For Literal Truth: even if Spinoza does not claim that God is Plato's Form of the Good, he easily could have (recall the analogy of the atheist). For Defining Features: none of the above six listed features of God involve mind-dependence or relativism, nor do they appeal to egoism. If we take Plato's metaphysics to be a clear example of moral realism on the three approaches, then, there are good reasons to say the same of Spinoza's.

\section{Spinoza's revisionism}

I now turn to the metaethical significance of Spinoza's revisionism about moral terms and concepts, which was touched on above. Spinoza's makes his revisionist attitude explicit in Book 3:

I know that in their common usage these words mean something else. But my purpose is to explain the nature of things, not the meaning of words. I intend to indicate these things by words whose usual meaning is not entirely opposed to the meaning with which I wish to use them. One warning of this should suffice. (E3da20expl, G II 195/19-24)

E3da20 concerns "Favor" and "Indignation," but, as the passages cited above show, it is hard not to see a similar attitude behind Spinoza's definitions of moral terms. ${ }^{38}$

What this means is that while Spinoza's system might imply the truth of some moral claims when literally construed by the standards of his own (or Plato's) revisionist definitions, those claims might not count as true when literally construed by the standard of their unrevised meanings. At least at an extreme, such an approach can depart from the tradition of moral realism. If, say, someone re-defined "good" as equivalent to "carbon," then they might be able to say something true with the sentence "there is good in everything that lives." That, however,

of moral precepts emanating from the divine nature at the beginning of Ep75. Another possible objection (suggested in correspondence by Matt Kisner) is that Plato's Form is, unlike Spinoza's God, transcendent. Since Plato's Form apparently stands in causal relations to the world, this comparison is hard to assess. Regardless, transcendence by itself is not metaethically significant on any approach to the realism/antirealism distinction.

${ }^{38}$ For one relevant discussion, see Curley, "Spinoza's Moral Philosophy." For a helpful general discussion of Spinoza's linguistic revisionism, see Laerke, "Spinoza's Language." 
would hardly be a way of establishing moral realism. Spinoza's revision is not as radical as the "good=carbon" revision. But the identification of virtue with power could be seen as a step in that direction. ${ }^{39}$

Nonetheless, this revisionism is by itself neutral on whether Spinoza is a moral realist. As noted above, none of the three approaches to moral realism preclude revisionism. There is good reason for this, since the paradigmatic realist Plato is almost certainly a revisionist. Moreover, consider the self-described 'atheist' from the previous section. Imagine that that philosopher offers a radically revisionist theological semantics, defining "God" as "largest quantity." That philosopher then states, "God does not exist," but continues to accept the existence of a supernatural, intelligent, benevolent creator. Despite her revisionist semantics, such a philosopher would still rightly be counted as a realist about God, whether because of her similarity to paradigm theists, her providing a system on which some theological claims would be literally true (albeit not on her semantics), or her positing an entity with the relevant general features.

\section{Realist or anti-realist?}

We have seen that there are various realist and anti-realist elements in Spinoza's philosophy, though all of those elements could be explored in further detail. Different elements suggested realism or anti-realism in different ways, according to the three approaches mentioned in $\S 1$. Given this complexity, one might be tempted to deny that there is any clear sense in which Spinoza is either a moral realist or an anti-realist.

Recall, though, that the point of the realism/anti-realist distinction is to capture a longstanding debate in philosophy. Recall also that it is enough for moral realism (at least on the Literal Truth Approach) if even one moral claim, literally construed, is true. The claim in question does not even need to be one made by the philosopher under consideration. If any of the considerations described in $\S 3.1-\S 3.3$ hold, then this sufficiency condition is met, whether with "we ought to pursue virtue for its own sake," "virtue is real," or with "the Form of the Good exists." In more general terms, my claim is that when determining whether some figure is a moral realist, we should weigh realist elements more heavily than anti-realist elements. This is, I think, a feature of the Literal Truth Approach worth taking seriously, and one that Spinoza's commentators have not paid enough attention to. As an analogy: realism about dragons would be

\footnotetext{
${ }^{39}$ Consider Spinoza on human freedom. Spinoza rejects human freedom in the ordinary sense (see E1app), yet later endorses a revised notion (see, e.g., E4p67d, E5pref). This would make it misleading to classify Spinoza as a simple realist or anti-realist about human freedom.
} 
vindicated if even only a few dragons existed and most beliefs about dragons were false. We have enough, I think, for us to count Spinoza as a moral realist, even while acknowledging that his view has some anti-realist features.

Regardless of how we classify Spinoza metaethically, though, I hope to have shown that the complexities of Spinoza's views offer important challenges for figuring out what it would mean for morality to be real. ${ }^{40}$

${ }^{40}$ Thanks to Paul Franco, Matt Kisner, Yizhak Melamed, Spencer Paulson, Mike Raven, Bill Talbott, Melanie Tate, and especially to John Grey, John Morrison, and Michael Rosenthal. 


\section{Works Cited}

Annas, Julia. 1978. "Plato and Common Morality," The Classical Quarterly 28:2, 437-451.

Ayers, Michael (ed.). 2008. Rationalism, Platonism and God. Oxford: Oxford University Press.

Bennett, Jonathan. 1984. A Study of Spinoza's Ethics. Indianapolis: Hackett Press.

Curley, Edwin. 1988. Behind the Geometrical Method. Oxford: Oxford University Press.

-- 1973. "Spinoza's Moral Philosophy.” In Marjorie Grene (ed.), Spinoza: A Collection of Critical Essays. Notre Dame: University of Notre Dame Press, 354-76.

Dreier, James. 2004. "Meta-Ethics and the Problem of Creeping Minimalism." Philosophical Perspectives 18, 23-44.

Findlay, Stephen. 2007. “Four Faces of Moral Realism.” Philosophy Compass 2, 1-30.

Fine, Kit. 2001. “The Question of Realism.” Philosophers' Imprint 1:1, 1-30.

Frankena, W. K. 1977. "Spinoza on the knowledge of good and evil." Philosophia, 7(1), 15-44.

Garrett, Don. 1996. “Spinoza's Ethical Theory.” In Don Garrett (ed.), The Cambridge Companion to Spinoza. Cambridge: Cambridge University Press. 267-314.

-- 1990. “A Free Man Always Acts Honestly, Not Deceptively': Freedom and the Good in Spinoza's Ethics.” In Spinoza: Issues and Directions, edited by Edwin Curley and PierreFrançois Moreau. Leiden: Brill, 221-238.

Grey, John. 2013. "'Use Them At Our Pleasure': Spinoza on Animal Ethics," History of Philosophy Quarterly 30:4, 367-388.

Harman, Gilbert. 2015. “Moral Relativism is Moral Realism.” Philosophical Studies 172, 855863. 
Hart, Alan. 1983. Spinoza's Ethics, Part I and II: A Platonic Commentary. Leiden: E.J. Brill.

Hegel, Georg Wilhelm Friedrich. 1995. Lectures on the History of Philosophy, Vol. 3. E. S.

Haldane and F. H. Simson (trans.). Lincoln: University of Nebraska Press.

Jarrett, Charles. 2014. "Spinozistic Constructivism.” In Kisner and Youpa, Essays on Spinoza's Ethical Theory, 57-85.

Kain, Patrick. 2006. "Realism and Anti-Realism in Kant's Second Critique." Philosophy Compass 1:5, 449-465.

Kristeller, Paul. 1984. "Stoic and NeoPlatonic Sources of Spinoza's Ethics." History of European Ideas 5:1, 1-15.

Kisner, Matthew J. 2011. Spinoza on Human Freedom. Cambridge: Cambridge University Press.

-- 2010. “Perfection and Desire: Spinoza on the Good.” Pacific Philosophical Quarterly 91:1, 97117.

-- 2009. "Spinoza's Benevolence: The Rational Basis for Acting to the Benefit of Others." Journal of the History of Philosophy 47:4, 549-68.

Kisner, Matthew and Youpa, Andrew (eds.). 2014. Essays on Spinoza's Ethical Theory. Oxford: Oxford University Press.

Koistinen, Olli and Biro, John (eds). 2002. Spinoza: Metaphysical Themes. Oxford: Oxford University Press.

Laerke, Morgens, 2014. "Spinoza's Language." Journal of the History of Philosophy 52:3, 519548.

LeBuffe, Michael. 2014. "Necessity and the Commands of Reason." In Kisner and Youpa, 197220. 
-- 2010. From Bondage to Freedom: Spinoza on Human Excellence. Oxford: Oxford University Press.

Mackie, John. 1977. Ethics: Inventing Right and Wrong. New York: Penguin Books.

Marshall, Colin. Forthcoming. "Schopenhauer and Non-Cognitivist Moral Realism," Journal of the History of Philosophy.

-- Forthcoming. "Kant's derivation of the moral 'ought' from a metaphysical 'is."' In Nick Stang and Karl Schafer, The Sensible and Intelligible Worlds. Oxford University Press.

Melamed, Yitzhak. 2009. "Spinoza's Metaphysics of Substance: The Substance-Mode Relation as a Relation of Inherence and Predication." Philosophy and Phenomenological Research 78:1, $17-82$.

Miller, Jon. 2005. “Spinoza's Axiology”, in Oxford Studies in Early Modern Philosophy, Vol. 2 Oxford: Oxford University Press, 149-172.

Nadler, Stephen. 2014. “The Lives of Others: Spinoza on Benevolence as a Rational Virtue.” In Kisner and Youpa, Essays on Spinoza's Ethical Theory, 41-56.

Plato. 2004. Republic, C.D.C. Reeve (trans.). Indianapolis: Hackett.

-- 1992. Theaetetus. In Bernard Williams, Myles Burnyeat (eds.), M. J. Levett (trans.). Indianapolis: Hackett.

Rauscher, Frederick. 2002. "Kant's Moral Anti-Realism.” Journal of the History of Philosophy 40:4, 477-499.

Rosenthal, Michael. 2014. "Politics and Ethics in Spinoza: The Problem of Normativity." In Kisner and Youpa, 85-101.

Rutherford, Donald. 2008. "Spinoza and the Dictates of Reason." Inquiry 51:5, 485-511. 
Savan, David. 1958. "Spinoza and Language." The Philosophical Review 67:2, 212-25.

Sayre-McCord, Geoffrey (ed.). 1988. Essays on Moral Realism. Ithaca: Cornell University Press.

Schopenhauer, Arthur. 2010. On the Basis of Morals, in Two Fundamental Problems of Ethics.

D. Cartwright and E. Erdman (trans. and eds). Oxford: Oxford University Press.

Spinoza, Baruch. The Collected Works of Spinoza, Edwin Curley (trans. and ed.). Princeton:

Princeton University Press.

Steinberg, Diana. 1984. "Spinoza's Ethical Doctrine and the Unity of Human Nature."

Journal of the History of Philosophy 22:3, 303-324.

Street, Sharon. 2008. "Reply to Copp: Naturalism, Normativity, and Varieties of Realism Worth Worrying About." Philosophical Issues 18, 207-28.

Wright, Crispin. 1992. Truth and Objectivity. Cambridge, MA: Harvard University Press.

Youpa, Andrew. 2009. "Spinoza's Theory of the Good.” In Olli Koistinin (ed.), The Cambridge

Companion to Spinoza's Ethics. Cambridge: Cambridge University Press, 242-57.

-- 2010a. “Spinoza's Model of Human Nature.” Journal of the History of Philosophy 48:1, 61-76.

-- 2010b. “Spinoza's Theories of Value.” British Journal for the History of Philosophy 18:2, 20929.

Zuk, Peter. 2015. “A Third Version of Constructivism: Rethinking Spinoza's Metaethics.” Philosophical Studies 172:10, 2565-2574. 